DOI 10.2478/auseb-2020-0003

\title{
Ownership Structure and the Risk: Analysis of Indian Firms
}

\author{
Ranjita KUMARI, ${ }^{1}$ Nishant KUMAR ${ }^{2}$ \\ ${ }^{1}$ Research Scholar, Department of Business Administration, University of Lucknow \\ e-mail: bhu.ranjita@gmail.com \\ ${ }^{2}$ Assistant Professor, Department of Business Administration, University of Lucknow \\ e-mail:nishchalvrm@gmail.com
}

\begin{abstract}
Considering the positive relationship between ownership and firm performance in the corporate finance literature, the paper aims to investigate the effect of ownership structure on the risk associated with the firm. Portfolio theories state that an investment with a high return is expected to be associated with high risk; so, it can be argued that ownership should have a positive relation with risk too. However, another explanation is that since large shareholders, such as promoters and financial institutions, have a significant stake in firms, in developing countries like India they will avoid excess risk taking, and so there should be a negative relationship between ownership and risk associated with firms. Analysing Nifty-500 companies for the period of 2006/07-2015/16, the study has found that Indian blockholders are in general risk-averse. Results also suggest that profitability and growth opportunities have negative effects on risk, which again establishes the positive association between ownership structure and profitability.
\end{abstract}

Keywords: promoters, institutions, beta, Nifty-500

JEL Classification: G32

\section{Introduction}

According to Ghysels et al. (2005), risk-return trade-off is so fundamental in financial economics that it can be described as the "first fundamental law of finance". This means that a great performance implies great risk. Although it is prominently used in portfolio analysis, this trade-off can be applied to projects and businesses too, and a firm is a combination of many projects and businesses. Another major theory in corporate finance, the agency theory, underlines the issues related to the separation of ownership and control in the businesses. There is substantial literature that discusses the relationship between ownership and firm value, defining ownership in numerous ways. The findings may not be very 
conclusive but generally support the idea that family ownership has a positive effect on firm value, while studies on institutional and managerial ownership have presented varied results. We argue that different categories of shareholders have varied goals, and they act and make decisions accordingly, which defines the prospects of the firm. Since in countries like India promoters and other blockholders are central in decision making, their acts are key to risk and the profit earned by a business. The paper intends to examine the effect of ownership variables - promoters and institutions - on the market risk associated with Indian firms by using the data of Nifty-500 companies.

The rest of the paper is organized as follows: Section 2 reviews the literature related to ownership and firm performance as well as ownership and risk and outlines the testable hypotheses. Section 3 explains the sample and methodology, Section 4 exhibits the empirical results, and Section 5 concludes.

\section{Literature Review}

\section{Ownership and Firm Performance}

Berle and Means (1932) are of the view that managers may behave irresponsibly and will enjoy free-ridership as shareholders will be diffused and lack incentives to control and monitor them. They may follow the path that will maximize their own benefits instead of welfare and the wealth maximization of the shareholders. Based on this idea, many authors strive to understand why managers behave in a particular way and how their goals could be aligned to that of the shareholders. In this endeavour, a stream in finance divided firms into owner-controlled firms and manager-controlled firms, and found that manager-controlled firms used to create less profit than owner-controlled firms. They have reasoned that since managers have less opportunity and less incentive to take risks, they do not try to maximize profit but to create a consistent growth story. In 1976, Jensen and Meckling suggested some measures to align managerial goals to those of shareholders. One of those methods is the allotment of shares to managers so that their interests could be aligned to that of other shareholders. However, at an initial stage, such research studies were generally confined to the USA only, where large corporations were evolving very swiftly. When such research studies were carried out around the world, it was found that the presence of blockholders and concentrated ownership is more common around the world.

In general, blockholders such as families, financial institutions, and governments, are present in firms' shareholding with controlling power. So, the focus shifted to how these blockholders affect the operation and performance of a firm. As far as family ownership is concerned, Anderson and Reeb (2003) found that it is 
prevalent and substantial and that family firms are better than non-family firms when measured through profitability. Villalonga and Amit (2004) observed that the value of a firm is higher if the founder serves as CEO, but it is lower where the descendants serve as CEO. Further, in 2010, they found that founding families are more likely to retain control when they give the firm a competitive advantage, while an "outsider" or non-founding family will retain control when it has some private benefits of that control. Maury (2006) presented the evidence that familycontrolled firms perform better than firms controlled by non-family owners in the case of Western European firms and is of the view that this could be due to lower agency costs. For Japanese firms, Saito (2008) found that when firms are run by the founders they used to trade at a premium, but when they are run by descendants the results are mixed. As far as Indian firms are concerned, Khanna and Palepu (2000b) found that well-diversified business groups, which are in general owned by families, perform better than any other group of firms in the economy.

In the case of institutional shareholding, McConnell and Servaes (1990) presented a significant positive relation between Tobin's Q and the shares owned by institutional investors for US firms. For Japanese firms, the relation between the main bank and firm value has been found negative and non-linear by Morck et al. (2000). In his study on emerging countries, Lins (2003) found that a larger non-management blockholder's presence is positively related to Tobin's Q, and they also control the management to be entrenched and reduce their negative impact on the firm's value. Based on these studies, it can be inferred that the behaviour and motivation of blockholders are very specific, and they have considerable bearing on the value and performance of the firms.

\section{Risk}

Risk is the unpredictability about future returns and profitability. It helps investors decide whether to invest in a business or not. There are several ways by which unpredictability could be measured. Variations in profitability are one of those measures which have been used by Cheng (2008) and Kakani et al. (2001). McEachern (1976) used CAPM beta as their measure of risk. Many authors have applied methods using equity and market returns to calculate systematic and idiosyncratic risk. Amihud et al. (1983) calculated systematic risk as the coefficient of equity return on market return and variance of error term as the unique risk of the firm. Nguyen (2011) used the Fama and French three-factor model to calculate systematic risk, the standard deviation of the firm's monthly stock return to calculate total risk, and standard deviation of the residuals to measure the firm-specific risk. Chen et al. (1998) measured total risk as to the standard deviation of the daily returns on the company's stock, while unsystematic risk was measured as the standard 
deviation of the residual error term. Similarly, Low (2006) used the variance of daily equity return as a measure of risk. Reliable earning is crucial for the overall performance of the firm, and unsteady earnings reflect themselves through capital market operations and specify the risk associated with the performance of a firm. On this ground, the study tried to present the possible link between ownership and market risk.

\section{The Relation between Ownership and Risk}

In general, managerial literature on this topic categorizes firms into two groups - on the basis of an arbitrarily chosen cut-off point: firms controlled by ownermanagers and manager-controlled firms. Monsen and Downs (1965) have a viewpoint that top managers of large firms do not intend to maximize profit but try to realize a steady growth of earnings along with steadily rising stock prices and as a result attain less variability of profits. This could be probably one of the reasons for a slower growth than if they sought to maximize profits. McEachern (1976), too, found that there is more market-related risk in the owner-managed firms. Stano (1976) has a different view, according to which, since management-controlled firms are more leveraged and the rate of return is highly volatile, growth rate is low and performance is poor. Amihud and Lev (1981) have pointed out that firms with managerial control are more inclined to indulge in diversifying mergers to reduce the risk related to their financial assets as well as the risk of their income from their job with the company. All these studies are based on agency theory, which is based on the notion that managers follow different goals than shareholders' wealth maximization. However, in the case of India, firms are run by owner-managers, and they have in general decisive control over firms, while it has been argued in the literature that in developing countries like India the problem is not to control the free-ridership of managers but to align the interests of the majority and minority shareholders (J. R. Varma, 1997).

In recent literature, Nguyen (2011) has found a positive relationship between family ownership and a firm's idiosyncratic risk, while bank ownership is negatively related. He argues that banks are risk-averse, and they choose less risky projects over risky projects with higher returns, while family firms appeared to be managed with the aim of handing it over to the next generation. Accordingly, they may be able to take on high-value-creating projects due to their longer time horizon. Cheng (2008) has found that board size and corporate performance are negatively related and argues that larger boards make many compromises before reaching a consensus, which results in less extreme decisions and less extreme performances. Jiraporn et al. (2015) argue that effective governance imposes stricter norms on managers; therefore, decisions are relatively balanced and less extreme, and there is less variability in corporate performance. They have shown 
that board, ownership, and compensation are significantly negatively related to risk. The firm-level analysis of companies in the United States by John et al. (2008) reveals that bank financing and unionization are both negatively related with corporate risk taking.

Results on the relationship between ownership and risk are rather inconclusive. Since, in general, authors outlined a positive link between family ownership and firm value (Khanna and Palepu, 2000b; Anderson and Reeb, 2003; Villalonga and Amit, 2004; Maury, 2006; Saito, 2008), it is hypothesized that family firms can take more risks. In most of the companies in India, promoters have a majority stake; we hypothesize a positive relationship between promoters' shareholding and risk.

Hypothesis 1: Promoters' ownership is positively related to the firm's risk.

Institutional shareholders have exhibited a mixed relationship with firm performance. They are classified into different categories by authors, so a direct comparison between the results is a tricky task; however, evidence from India is presented here. Khanna and Palepu (2000a) observed a negative effect of domestic financial institutions (DFIs) on firm performance (PQ ratio) in India, while foreign institutional investors are found to affect firm performance significantly and positively. Through a comprehensive analysis of domestic financial institutions, Amiya Sahu (2015) observed that DFIs are not good monitors. Kakani et al. (2001) presented the evidence of the significant negative impact of domestic institutional investors and shares owned by retail investors on firm performance and found a positive, although insignificant, relation with risk for Indian firms. John et al. (2008) and Nguyen (2011) have shown a negative relation between firm risk and the presence of bank finance for the US and Japan. Based on the literature, we hypothesize a negative relation between institutions' shareholding and risk for Indian firms because financial institutions are major debt providers to businesses too, and that prevents them from getting involved in risky projects.

Hypothesis 2: Institutional shareholders are negatively related to the firm's risk.

\section{Research Methodology}

\section{Sample and Data Sources}

The sample of this analysis comprises firms listed in NSE India. Nifty-500 was taken as the sample for the study, representing around $94 \%$ of the total market capitalization of all listed firms in NSE. To increase the sample size, all firms which were part of NSE 500 during the period of analysis, that is, 2006/07-2015/16, were 
also included in the sample. Since government firms are assumed to pursue other goals than profit maximization, they have been excluded from the analysis. Gupta (2005) and Boubakri et al. (2018) also pointed out that state-owned firms did not have a strong incentive to maximize efficiency, which a private owner will pursue with dedication. Thomsen and Pedersen (1996) argued that high government ownership reflects high government interventions. In the case of India, for example, one of the major goals of the Indian government is to reduce social and economic discrimination, and for that purpose government organizations are obliged to provide reservation in recruitment for marginal classes. Such policies are not mandatory for privately owned firms. Government firms get frequent bailouts from central agencies that are not available so easily for private companies. In these ways, government-owned firms are quite different from privately owned firms. Financial institutions have also been kept out from the analysis as their reporting pattern and asset structure are different from the rest of the firms. After eliminating instances that have missing data, the final sample includes 3,868 observations, representing 485 firms from 14 industries in which the manufacturing sector is prominent. All data for this study have been obtained from the CMIE database.

\section{Variables of Interest}

\section{Performance Measure}

The beta of the stock has been utilized as a measure of risk. It is one of the most famous techniques to measure the systematic risk associated with stock return, and in many ways it can be considered to be more meticulous than other risk measures like variability in accounting profitability and equity returns, which are in general criticized for accounting manipulations and subjectivity (Jayesh Kumar, 2004; Hawawini et al., 2003). It is based on CAPM, which is a wellrecognized method to measure risk and follow a strict formula of calculation. One crucial point is raised by Demsetz and Lenn (1985) about the frequency of data availability. Equity returns data can be collected monthly and in recent times on a daily basis also, while accounting data could be available quarterly at the best. This point is purely statistical, but it is well-documented that a large sample is a solution to many issues related to estimation. Low (2006) has argued that the estimation of a firm's risk is a critical issue because numerous factors on which the calculation of risk depends are those for which data is not readily available. CAPM beta has also a few serious issues, as, for instance, Ross (1976) stated that it is not only an efficient portfolio's return that determines stock return, but there are many other forces behind. However, it is also true that, in spite of all the controversy around it, it has been widely in use. Although the beta is 
considered to be determined by the forces outside of the firm, it can be argued that the severity of such forces is felt more by frail firms. This way, a debt-ridden firm will be hit harder by the increase in interest rates than all-equity firms. To avoid accounting manipulations and subjective imputations, CAPM beta has been used in this analysis as a measure of risk.

\section{Ownership Variables}

SEBI (Securities and Exchange Board of India) has classified shareholders broadly into two categories - promoters and promoters group and public shareholders. Public shareholders are further classified into two categories: retail and institutional shareholders. Promoters and promoters group and institutional shareholders have been included in this study because they hold a larger portion of total shares, have knowledge of the business and the market, and are in the position to define corporate policies, which in turn decide the risk and return of the firm. Promoters' shareholding is measured through the percentage of total shares held by promoters, and institutional shareholding is measured by the percentage of total shares held by institutions.

\section{Control Variables}

Based on previous research, the study includes few control variables, which are expected to affect the measure of risk, beta. McEarchen (1976), Nguyen (2011), and Jiraporn (2015) considered size as a determinant of risk. In this study, size is measured through the natural logarithm of sales. It is likely to affect a firm's risk because it can be argued that large-sized firms have greater ability to absorb economic volatility than smaller firms. Damodaran (2006: 51) discussed three determinants of Beta: industry of the firm; operating leverage, that is, fixed assets to total assets ratio; financial leverage, that is, debt-equity ratio. The same definitions of these variables have been adopted for this study. Similarly, Mandelker and Rhee (1984) have also found the degree of financial leverage and operating leverage to be the major determinants of risk, which they measured through beta because these two magnify the intrinsic business risk. PBV ratio has been included in the analysis as a proxy of growth opportunities available to the firm. It is the ratio of market value of equity divided by book value of equity. ROA has been incorporated in the belief that changes in profitability affect market sentiments and risks associated with the firm; it is ratio of net income to book value of total assets multiplied with hundred. To control for industry effect, industry dummies based on the NIC (National Industrial Classification) classification of industries have been included in the model. Similarly to control for macroeconomic effects, time dummies have also been included in the model. 


\section{The Empirical Model}

The panel data model is as follows:

$$
\begin{aligned}
\text { Risk }= & \beta_{0}+\beta_{1}{ }^{*} \text { Promoters }_{i t}+\beta_{2}{ }^{*} \text { Institutions }_{i t}+\beta_{3}{ }^{*} \text { Size }_{i t}+\beta_{4}{ }^{*} O L_{i t}+\beta_{5}{ }^{*} F L_{i t} \\
& +\beta_{6}{ }^{*} P B V_{i t}+\beta_{7}{ }^{*} \text { ROA } \\
\text { it } & +\beta_{8}{ }^{*} \text { Industry dummy }{ }_{l}+\beta_{9}{ }^{*} \text { Time dummy }{ }_{l}{ }^{\prime}
\end{aligned}
$$

where risk is measured by beta for the period of 2006/07-2015/16, "promoters" represents the promoters" shareholding in the firm, "institutions" is the shareholding by institutions, "Size" is the natural logarithm of total sales, "OL" is operating leverage, "FL" is financial leverage, "PBV" is price to book value ratio, "ROA" is return on assets, "Industry dummy" is the dummy of each industry, and "Time Dummy" is the dummy allotted to each year from 2006-07 to 2015-16.

\begin{tabular}{|c|c|c|c|c|c|c|}
\hline Variables & Count & Mean & Median & $\begin{array}{l}\text { Standard } \\
\text { Deviation }\end{array}$ & Minimum & Maximum \\
\hline \multicolumn{7}{|c|}{ Ownership Variables } \\
\hline Promoters & 3,868 & 53.03 & 53.51 & 16.10 & 0 & 93.15 \\
\hline Institutions & 3,868 & 17.70 & 15.57 & 14.11 & 0 & 71.32 \\
\hline \multicolumn{7}{|c|}{ Control Variables } \\
\hline Size & 3,868 & 8.51 & 8.74 & 2.26 & -4.60 & 15.20 \\
\hline OL & 3,868 & 0.29 & 0.28 & 0.17 & $5.97 e-07$ & 0.93 \\
\hline FL & 3,868 & 1.71 & 0.64 & 13.25 & 0.01 & 437.91 \\
\hline PBV & 3,868 & 3.14 & 1.61 & 8.21 & 0 & 265.06 \\
\hline ROA & 3,868 & 5.54 & 4.76 & 8.48 & -120.8 & 115.83 \\
\hline $\begin{array}{l}\text { Industry } \\
\text { dummy }\end{array}$ & 14 & & & & & \\
\hline $\begin{array}{l}\text { Year } \\
\text { dummy }\end{array}$ & 10 & & & & & \\
\hline \multicolumn{7}{|c|}{ Dependent Variable } \\
\hline Beta & 3,868 & 1.06 & 1.04 & 0.38 & 0.09 & 2.9 \\
\hline
\end{tabular}

Table 1. Descriptive statistics

Table 2 exhibits the descriptive statistics on ownership, control, and dependent variables. It is clearly visible that in India promoters are the dominant shareholders as the table indicates that mean promoters' shareholding is as high as 53.03 in the largest 500 companies of the country. According to Khanna and Palepu (2005), concentrated ownership is an outcome of the institutional void, which is a key 
feature of Third World countries. Although the government has mandated all the listed companies to reduce their promoters holding up to a maximum of $75 \%$, there are few companies having greater promoters' ownership. Institutional shareholding here includes all institutions comprising banks, mutual funds, insurance companies, FIIs, etc. with the argument that all institutions are profitoriented and are intensely cautious about their interests. Companies included in the analysis are quite distinct from one another, as company-specific information reflects. Sales measured in log vary from 15.20 to -4.60 (0.01 Cr.) and ROA from 115.83 to -120.8 . The case is similar for other variables including the dependent variable Beta.

Table 2. Test results for the OLS estimation

Tests $\downarrow$

\begin{tabular}{llll}
\hline Test of poolability (Breusch-Pagan LM test) & $\chi^{2}=4988$, & $\left(2.2 \mathrm{e}-16^{* * *}\right)$ & $\mathrm{DF}=1$ \\
\hline Test for model selection (Hausman test) & $\chi^{2}=155.28$ & $\left(2.2 \mathrm{e}-166^{* *}\right)$ & $\mathrm{DF}=18$ \\
\hline Test for cross-section dependence (Pesaran CD test) & $\mathrm{Z}=0.287$ & $(0.7739)$ & \\
\hline Test for serial correlation (Breusch-Godfrey) & $\chi^{2}=1025.1$ & $\left(2.2 \mathrm{e}-16^{* * *}\right)$ & $\mathrm{DF}=1$ \\
\hline Testing for unit roots/stationarity (Dickey-Fuller test) & $\mathrm{D}-\mathrm{F}$ coef $=-21.382 \quad(0.01)$ & \\
\hline Test for heteroskedasticity (Breusch-Pagan test) & $\mathrm{BP}=471.84(2.2 \mathrm{e}-16 * * *)$ & $\mathrm{DF}=29$ \\
\hline
\end{tabular}

Note: the numbers in parentheses are p-values of t-statistics. ${ }^{* *}$ indicates significance at 0.1 percent level, ${ }^{* *}$ indicates significance at 1 percent level, * indicates 5 percent level, + indicates significance at 10 percent level.

\section{Tests Used for Data Consistency}

First of all, OLS (Ordinary Least Squares) estimation has been carried out and checked for the presence of various statistical issues that affect the estimation of coefficients. Since two ownership variables have been included in the analysis, the presence of multicollinearity cannot be ruled out, and so VIF analysis is performed, which suggests the non-existence of multicollinearity (3.85 for promoters and 4.11 for institutions). Then, to check for the presence of panel effects, the BreuschPagan (LM) test was applied in the model. It has been found that the panel effect is significant and panel data models are needed. To compare the panel data models that are fixed effects and random effect, the Hausman test was used, whose results were also significant and suggested the use of fixed-effects models. To search out the presence of cross-correlation among entities, Pesaran's cross-dependence test was applied. The test suggests the absence of a significant level of crossdependence. Serial correlation is another problem that used to be present in data with a time 
dimension. The Breusch-Godfrey test was used to detect serial correlation, and a strong existence was found in this respect. Further, the augmented Dickey-Fuller test was employed to detect non-stationarity, according to which the data are stationary. And, lastly, to test for heteroskedasticity in the data, the Breusch-Pagan test was applied, which showed that data was not homoskedastic. Table 2 exhibits the results of tests performed on OLS.

Since the Pesaran test suggests an absence of cross-dependence, two problems - serial correlation and heteroskedasticity - that could hinder the inference, need to be resolved. The Arellano estimator (1987) was applied to control for the simultaneous occurrence of serial correlation and heteroskedasticity. Based on the assumption of fixed $\mathrm{T}$ and large $\mathrm{N}$, Arellano extended White's heteroskedasticityconsistent estimators for panel data in the following form:

$$
\beta=\left(X^{\prime} X\right)^{-1} \sum_{i=1}^{n} X_{i}^{T} u_{i} u^{T} X_{i}\left(X^{\prime} X\right)^{-1},
$$

where:

$-\left(\mathrm{X}^{\prime} \mathrm{X}\right)^{-1}$ are breads and

$-\sum_{i=1}^{n} X_{i}^{T} u_{i} u^{T} X_{i}$ is the covariance to be added in regression, also called meat of the
sandwich (Arellano, 1987; Millo, 2017).

\section{Results and Discussion}

Table 3 presents the results of the analysis. The study has found that the impact of promoters is negative (-0.004) and highly significant with the p-value (2.02-07), and thus the first hypothesis that promoters have positive impact on risk is rejected. It indicates that large investment by promoters prevents them from getting involved in risky projects. A possibility could be that they are actually involved in a few risky projects, and making profits for the business and the market renders their presence positive in the belief that they will keep the operations intact. Here a comparison between market-related risk and risk related with accounting profits will perhaps give us more insight. Institutional investors are also negative (-0.003) and significant (0.000), which was expected and supported by literature. Since many large financial institutions are owned by the government, due to the extensive employment they make possible and the many deposits of the poor classes that they manage, the government has strict norms for them to follow when investing and lending their funds. Again, banks and financial institutions are the largest loan 
providers to companies too because the debt market is not well-developed here, and so they avoid excess risk taking due to their commitments to their customers and other stakeholders.

Table 3. Regression result for fixed-effects model

\begin{tabular}{ll}
\hline Independent Variables $\downarrow$ Estimates (p-values) \\
\hline Promoters & $-0.004(2.02-07)^{* * *}$ \\
\hline Institutions & $-0.003(0.000)^{* * *}$ \\
\hline Size & $0.007(0.284)$ \\
\hline OL & $-0.279(0.000)^{* * *}$ \\
\hline FL & $0.000(0.188)$ \\
\hline PBV & $-0.003(0.034)^{*}$ \\
\hline ROA & $-0.13(2.2 \mathrm{e}-14)^{* * *}$ \\
\hline Intercept & $1.447(2.2 \mathrm{e}-16)^{* * *}$ \\
\hline Year Dummy & Included \\
\hline Industry Dummy & Included \\
\hline F value & $33.326(2.2 \mathrm{e}-16)^{* * *}$ \\
\hline Adjusted $\mathbf{R}^{2}$ & 0.195 \\
\hline
\end{tabular}

Note: the numbers in parentheses are p-values of t-statistics. ${ }^{* *}$ indicates significance at 0.1 percent level, ** indicates significance at 1 percent level, * indicates 5 percent level, + indicates significance at 10 percent level.

As far as control variables are concerned, size and financial leverage (FL) have positive but insignificant effect (with p-values of 0.284 and 0.188 respectively), while ROA has a very significant and negative impact (with a p-value of $2.2 \mathrm{e}-14$ ). It seems that profits are rather important for the market, and if a firm performs consistently, the risk, projected by the market, will be smaller. Operating leverage (OL) is also negatively and significantly (with the p-value 0.000 ) related to market risk, which indicates that the market prefers firms with higher operating leverage. Most of the firms included in this study being in the manufacturing sector, which requires a relatively higher level of fixed assets, could be a reason for obtaining such result. PBV, which indicates the growth prospect of the firm, is also negatively and significantly (p- value is 0.034) related to market risk. Nguyen (2011) is of the view that growth firms face high uncertainty regarding their future cash flows, and so the higher the PBV (MBVA, in his study) ratio, the higher will be the risk. One of the explanations for such difference could be that the sample includes the largest firms, and the market believes in their competence because in this country the largest firms are generally owned by big business houses, and they have created wealth for shareholders in the long run. 


\section{Conclusions}

Using the estimation procedure that is consistent with the presence of heteroskedasticity and serial correlation, the study observed that concerning India both promoters and institutional shareholders are risk-averse. The cautious attitude of institutional shareholders is expected and supported by the literature too; however, the negative impact of promoters, which is a close substitute of family ownership in India, needs serious discussion because family ownership has been found in literature to be positively associated with risk taking in developed nations. The conclusion can be drawn that the institutional and societal obligations and political interference in India require a firm to behave conservatively. Simultaneously, this can indicate that financial markets and players are still in the developing stage in India, and so promoters do not get sufficient scope to diversify, and they behave conservatively to keep their businesses dependable as they used to have a large stake in the firm. Poor enforcement of corporate protection could be another factor to explain this finding.

\section{References}

Amihud, Y.; Kamin, J. Y.; Ronen, J. (1983). 'Managerialism', 'ownerism' and risk. Journal of Banking \& Finance 7(2): 189-196.

Amihud, Y.; Lev, B. (1981). Risk reduction as a managerial motive for conglomerate mergers. The Bell Journal of Economics 12(2): 605-617.

Anderson, R.; Reeb, D. (2003). Founding-family ownership and firm performance: Evidence from the S\&P 500. The Journal of Finance 58: 1301-1327.

Arellano, M. (1987). Practitioners' corner: Computing robust standard errors for within-groups estimators. Oxford Bulletin of Economics and Statistics 49(4): 431-434.

Berle, A.; Means, G. (1932). The modern corporation and private property. New York: McMillan.

Boubakri, N.; El Ghoul, S.; Guedhami, O.; Megginson, W. L. (2018). The market value of government ownership. Journal of Corporate Finance 50: 44-65.

Breusch, T. S.; Pagan, A. R. (1980). The Lagrange multiplier test and its applications to model specification in econometrics. The Review of Economic Studies 47(1): 239-253.

Chen, C. R.; Steiner, T. L., Whyte, A. M. (1998). Risk-taking behavior and management ownership in depository institutions. Journal of Financial Research 21(1): 1-16.

Cheng, S. (2008). Board size and the variability of corporate performance. Journal of Financial Economics 87(1): 157-176. 
Damodaran, A. (2006). Damodaran on valuation, security analysis for investment and corporate finance. USA: John Willey \& Son. Inc.

Demsetz, H.; Lehn, K. (1985). The structure of corporate ownership: Causes and consequences. Journal of Political Economy 93(6): 1155-1177.

Ghysels, E.; Santa-Clara, P.; Valkanov, R. (2005). There is a risk-return trade-off after all. Journal of Financial Economics 76(3): 509-548.

Gupta, N. (2005). Partial privatization and firm performance. The Journal of Finance 60(2): 987-1015.

Hausman, J. A. (1978). Specification tests in econometrics. Econometrica: Journal of the Econometric Society 46(6): 1251-1271.

Hawawini, G.; Subramanian, V.; Verdin, P. (2003). Is performance driven by industryor firm-specific factors? A new look at the evidence. Strategic Management Journal 24(1): 1-16.

Jensen, M. C.; W. H. Meckling (1976). Theory of the firm: Managerial behavior, agency costs and ownership structure. Journal of Financial Economics 3: 305360.

Jiraporn, P.; Chatjuthamard, P.; Tong, S.; Kim, Y. S. (2015). Does corporate governance influence corporate risk-taking? Evidence from the Institutional Shareholders Services (ISS). Finance Research Letters 13: 105-112.

John, K.; Litov, L.; Yeung, B. (2008). Corporate governance and risk-taking. The Journal of finance 63(4): 1679-1728.

Kakani, R. K.; Saha, B.; Reddy, V. N. (2001). Determinants of financial performance of Indian corporate sector in the post-liberalization era: An exploratory study. NSE Research Initiative, Paper No. 5.

Khanna, T.; Palepu, K. (2000a). Emerging market business groups, foreign intermediaries, and corporate governance. In: Morck, Randall K. (ed.), Concentrated corporate ownership. University of Chicago Press. 265-294.

(2000b). Is group affiliation profitable in emerging markets? An analysis of diversified Indian business groups. The Journal of Finance 55(2): 867-891. (2005). The evolution of concentrated ownership in India: Broad patterns and a history of the Indian software industry. In: Morck, Randall K. (ed.), A history of corporate governance around the world: Family business groups to professional managers. University of Chicago Press. 283-324.

Lins, K. V. (2003). Equity ownership and firm value in emerging markets. Journal of Financial and Quantitative Analysis 38(1): 159-184.

Low, A. (2009). Managerial risk-taking behavior and equity-based compensation. Journal of Financial Economics 92: 470-490.

Mandelker, G. N.; Rhee, S. G. (1984). The impact of the degrees of operating and financial leverage on systematic risk of common stock. Journal of Financial and Quantitative Analysis 19(1): 45-57. 
Maury, B. (2006). Family ownership and firm performance: Empirical evidence from Western European corporations. Journal of Corporate Finance 12: 321-341.

McConnell, J. J.; Servaes, H. (1990). Additional evidence on equity ownership and corporate value. Journal of Financial Economics 27(2): 595-612.

McEachern, W. A. (1976). Corporate control and risk. Economic Inquiry 14(2): 270-278.

Millo, G. (2017). Robust standard error estimators for panel models: A unifying approach. Journal of Statistical Software 82: 1-27.

Monsen, J.; Downs, A. (1965). A theory of large managerial firms. Journal of Political Economy 73: 221-236.

Morck, R.; Nakamura, M.; Shivdasani, A. (2000). Banks, ownership structure, and firm value in Japan. The Journal of Business 73(4): 539-567.

Nguyen, P. (2011). Corporate governance and risk-taking: Evidence from Japanese firms. Pacific-Basin Finance Journal 19(3): 278-297.

Patibandla, M. (2006). Equity pattern, corporate governance and performance: A study of India's corporate sector. Journal of Economic Behavior \& Organization 59(1): 29-44.

Pesaran, M. H. (2004). General diagnostic tests for cross section dependence in panels. University of Cambridge, Cambridge Working Papers in Economics, 435.

Radice, H. K. (1971). Control type, profitability and growth in large firms: An empirical study. The Economic Journal 81(323): 547-562.

Sahu, A. K. (2015). Does institutional shareholding affect firm value? An empirical analysis in Indian market. Available at: https://papers.ssrn.com/sol3/papers.cfm?abstract_ id=2413074. (Last accessed on: 9 June 2015).

Saito, T. (2008). Family firms and firm performance: Evidence from Japan. Journal of the Japanese and International Economies 22: 620-646.

Stano, M. (1976). Monopoly power, ownership control, and corporate performance. The Bell Journal of Economics 7(2): 672-679.

Stephen, R. (1976). The arbitrage theory of capital asset pricing. Journal of Economic Theory 13(3): 341-360.

Thomsen, S.; Pedersen, T. (1996). Nationality and ownership structures: The 100 largest companies in six European nations. MIR: Management International Review 36(2): 149-166.

Varma, J. R. (1997). Corporate governance in India: Disciplining the dominant shareholder. IIMB Management Review 9(4): 5-18.

Villalonga, B.; Amit, R. (2006). How do family ownership, control and management affect firm value? Journal of Financial Economics 80(2): 385-417.

Villalonga, B.; Amit, R. (2010). Family control of firms and industries. Financial Management 39(3): 863-904. 